University of Nebraska - Lincoln

DigitalCommons@University of Nebraska - Lincoln

U.S. Environmental Protection Agency Papers

U.S. Environmental Protection Agency

1973

\title{
Chronic Effect of Low pH on Fathead Minnow Survival, Growth and Reproduction
}

Donald I. Mount

Environmental Protection Agency

Follow this and additional works at: https://digitalcommons.unl.edu/usepapapers

Part of the Civil and Environmental Engineering Commons

Mount, Donald I., "Chronic Effect of Low pH on Fathead Minnow Survival, Growth and Reproduction" (1973). U.S. Environmental Protection Agency Papers. 14.

https://digitalcommons.unl.edu/usepapapers/14

This Article is brought to you for free and open access by the U.S. Environmental Protection Agency at DigitalCommons@University of Nebraska - Lincoln. It has been accepted for inclusion in U.S. Environmental Protection Agency Papers by an authorized administrator of DigitalCommons@University of Nebraska - Lincoln. 


\title{
CHRONIC EFFECT OF LOW pH ON FATHEAD MINNOW SURVIVAL, GROWTH AND REPRODUCTION
}

\author{
DONALD I. MounT* \\ Environmental Protection Agency, National Environmental Research Center, National Water Quality \\ Laboratory, Newtown Fish Toxicology Laboratory, 3411 Church Street, Cincinnati, Ohio 45244, \\ U.S.A.
}

(Received 26 June 1972)

\begin{abstract}
Fathead minnows (Pimephales promelas Rafinesque) were continuously exposed to reduced $\mathrm{pH}$ levels of $4.5,5.2,5.9,6.6$ and 7.5 (control) during a 13-month, one-generation test. Survival was not affected, even at the lowest $\mathrm{pH}$ tested. Fish behavior was abnormal, and fish were deformed at $\mathrm{pH} 4.5$ and 5.2. Egg production and egg hatchability were reduced at pH 5.9 and lower, and all eggs were abnormal. A pH of 6.6 was marginal for vital life functions, but safe for continuous exposure. Free carbon dioxide, liberated by the addition of sulfuric acid to reduce the $\mathrm{pH}$, may have had an unknown effect. The fish did not become accliminated to low $\mathrm{pH}$ levels.
\end{abstract}

\section{INTRODUCTION}

THE PROBLEM of acid mine drainage in the eastern part of the United States and the Water Quality Act of 1965 requiring water quality standards for receiving waters have increased the need to determine acceptable $\mathrm{pH}$ extremes for desirable aquatic organisms. A recent report by the EuropeAN INLAND FisHERIES ADVISORY COMMISSION (1969) summarized the literature regarding the effect of lowered $\mathrm{pH}$ on aquatic organisms and emphasizes the need for information on long-term effects on desirable aquatic life.

Data on the effects of acid waters on aquatic organisms are difficult to interpret because a reduction of $\mathrm{pH}$ produces changes in other water characteristics, especially free $\mathrm{CO}_{2}$, alkalinity, and the solubility and form of metals. Field observations in acid waters caused by mining operations are confused by the presence of iron and aluminum, in particular. Likewise, acid waters caused by drainage from such areas as peat bogs also contain many soluble acidic organic compounds. Indeed, the effect of decreased $\mathrm{pH}$ alone cannot be measured; the effects of other factors can only be minimized.

The review cited above identifies many characteristics common to unpolluted water, but only the concentration of free $\mathrm{CO}_{2}$ has a significant effect on lethal acid $\mathrm{pH}$ ranges. LLOYD and JORDAN (1964) found that $20 \mathrm{mg} \mathrm{l}^{-1}$ or more of free $\mathrm{CO}_{2}$ increased the toxic effects of reduced $\mathrm{pH}\left(\mathrm{TL}_{50} \mathrm{pH}\right.$ higher). Most lethal $\mathrm{pH}$ values from laboratory data reported in the literature are below 4.0. The report also states that growth of fish is known to be less in acid waters, but that no evidence is available to suggest that the effect is direct. Effects on the food supply, and perhaps the bacterial decomposition rate (involving nutrient availability), are implicated as significant factors in reduced growth rates.

The work described here was performed to measure the effect on reproduction and growth of fathead minnows (Pimephales promelas Rafinesque) of continued exposure

* Present address. Environmental Protection Agency, National Environmental Research Center, National Water Quality Laboratory, 6201 Congdon Boulevard, Duluth, Minnesota 55804, U.S.A. 
to decreased $\mathrm{pH}$ during their entire life cycle. Fatheads are important forage fish and are good bioassay animals. Concentrations of $\mathrm{CO}_{2}$ were above the level known to affect hydrogen-ion toxicity and may have contributed to the effects observed. The $\mathrm{CO}_{2}$ was allowed to remain, however, since $\mathrm{CO}_{2}$, as indicated by total acidity, is not rapidly lost from streams receiving acid mine drainage, but returns to normal slowly as reaeration occurs over several miles of the affected reach of the stream (U.S. Environmental Protection Agency, unpublished data). By leaving the free $\mathrm{CO}_{2}$ in the water, extant conditions were more nearly simulated.

\section{MATERIALS AND METHODS}

The test procedure was similar to that described by MounT and STEPHAN (1969). A proportional diluter (MOUNT and BRUNGS, 1967) was used as a metering device, and each of four water-delivery tubes operated a chemical metering apparatus (MouNT and WARNER, 1965) that added sufficient diluted sulfuric acid during each cycle of the diluter to produce the desired $\mathrm{pH}$. Proportional dilution of the most acid concentration to produce lesser concentrations was physically impractical in this water. After acid addition, two mixing chambers were necessary to mix the acid and water adequately. Nominal $\mathrm{pH}$ values in the test chambers were 4.5, 5.2, 5.9 and 6.6.

Test water was prepared by mixing hard water from a spring emerging from limestone strata with carbon-filtered, de-ionized Cincinnati tap water (from Ohio River) to produce a nominal total hardness of $200 \mathrm{mg}^{-1}$. The water was stored in a 5000 -gal underground, polyester-lined tank that was filled weekly and aerated continuously. A secondary tank provided water while more was being mixed. Flow rate through each test chamber was increased as the fish grew and become more active; the turnover time in each chamber was decreased from approximately 10 to $5 \mathrm{~h}$ during the test and the tank size was $12 \times 24$ in., with a water depth of 6 in.

Photoperiod was maintained at $16 \mathrm{~h}$ for the first 7 months, but because spawning did not begin promptly in all chambers, the photoperiod was reduced to $12 \mathrm{~h}$ and increased $1 \mathrm{~h}$ each week for 4 weeks. (Subsequent work has demonstrated that a constant photoperiod is acceptable.) A 16-h photoperiod was maintained thereafter, and the light intensity was sufficient for moderate algal growth.

The exposure was begun in August 1966 with seventy 1-day-old fry, hatched from laboratory-spawned eggs, in each of five tanks. The $\mathrm{pH}$ was gradually and equally reduced in the four test tanks, and as the $\mathrm{pH}$ reached the nominal value in each tank, no further reduction was made. Ten days were required to reach $\mathrm{pH} 4.5$. A tank of untreated test water served as the control (nominal pH 7.5). After 60 days each of the five test chambers was subdivided by a plastic screen, and 20 fish were selected at random from each treatment and randomly assigned to two groups of 10 and returned to the divided chamber. The test lasted for 13 months and was terminated on September $16,1967$.

Commercial trout food was fed daily, ad lib., and live organisms in the water supply supplemented this diet.

As the fish neared maturity, three one-half sections of asbestos-cement tile, $4 \mathrm{in}$. in diameter and $4 \mathrm{in}$. long, were placed in a row in each duplicate chamber as spawning substrate for the fish. Eggs, spawned on the under surface, were removed and counted before 10 a.m. each day, and any number of eggs was considered a spawning if spawning activity was not apparent. Eggs were incubated in small screen-bottomed cups 
(MounT, 1968), and hatchability was determined as the number of living fry from 50 eggs at 7 days. Two groups of 50 fry were placed in $6 \times 6$ in. compartments located in one corner of each tank and their growth measured for 30 days. Measurement was made to the nearest millimeter after aspirating each fish into a glass tube.

The test chamber with a nominal pH of 4.5 was monitored continuously on a circular chart recorder that also activated a relay interrupting the acid supply to that chamber at a $\mathrm{pH}$ of 4.2 and permitting the acid to flow again when the test chamber $\mathrm{pH}$ had reached 4.4. This protection was essential because a change in water hardness of 1-2 per cent, or an error in water delivery of 0.5 per cent, would cause the $\mathrm{pH}$ to fall to 4.1 , a pH lethal to the fish, even after 10 months of exposure. The $\mathrm{pH}$ in the chambers maintained nominally at 5.2, 5.9 and 6.6 was recorded about three times each hour by switching a flow of water from the chambers to the electrode and recording the $\mathrm{pH}$ on another meter. The system employed siphons and needle valves so that no aeration occurred until the water had passed the electrode. The $\mathrm{pH}$ in the four test chambers and the control was measured each weekday also by means of grab samples and a different $\mathrm{pH}$ meter.

Since the $\mathrm{TL}_{50}$ to fatheads was close to 4.0 but not definitely known, two acute tests were performed in the same system after the chronic test to determine the lethal $\mathrm{pH}$. Duplicate tests with 10 and 20 subadult fish, respectively, at three $\mathrm{pH}$ values were completed. The $\mathrm{pH}$ was recorded three times per hour during this test.

TABle 1. ChemiCal ANALYSES OF TEST WATER IN FOUR EXPERIMENTAL TANKS (NOMINAL pH 4.5, 5.2, 5.9 6.6) AND THE CONTROL, BASED ON WEEKLY GRAB SAMPLES

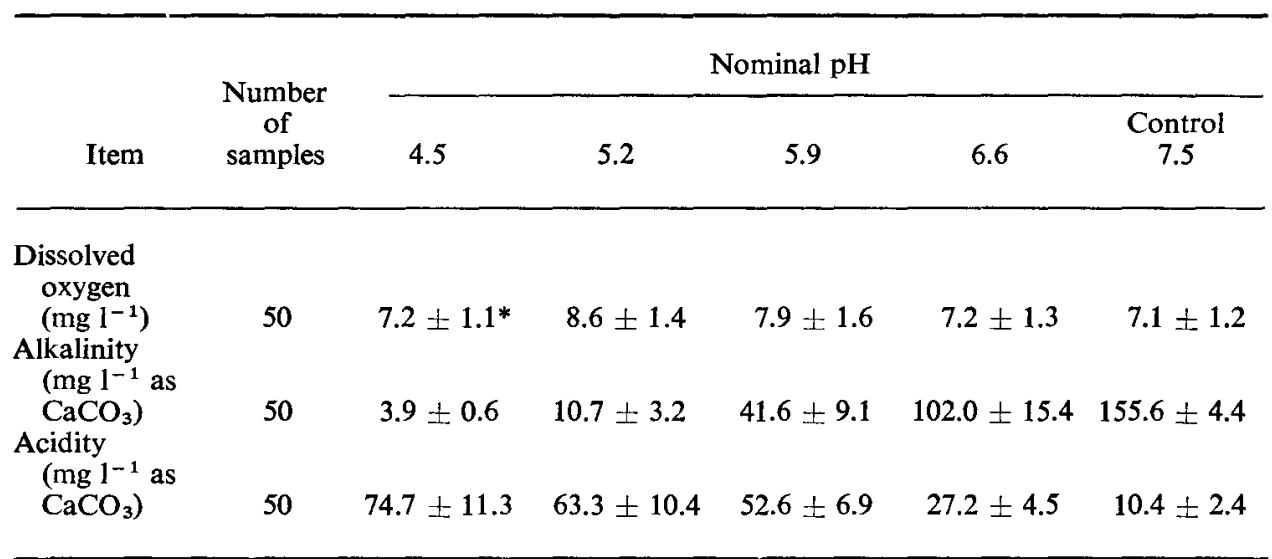

* Mean and standard deviation.

Dissolved oxygen, alkalinity, and acidity of the test water were determined weekly from grab samples (TABLE 1). Water hardness averaged $200.6 \mathrm{mg} \mathrm{l}^{-1}$ as $\mathrm{CaCO}_{3}$, with a standard deviation of $2.9 \mathrm{mg} \mathrm{1}^{-1}$, and the weekly mean temperature for the test was $22.3^{\circ} \mathrm{C}$ with a standard deviation of $1.04^{\circ}$ and a range of $20^{\circ}-24.5^{\circ}$. The quality of the $\mathrm{pH}$ control system as measured by continuous recording ( $\mathrm{pH} 4.5$ ) tests three times per hour ( $\mathrm{pH} 5.2,5.9,6.6$ ), and grab samples is shown in TABLE 2. Daily $\mathrm{pH}$ means were estimated ones, and the agreement was \pm 5 per cent. (Arithmetic means for $\mathrm{pH}$, 
TABLE 2. MEASURED PH VALUES IN THE TEST CHAMBERS (UPPER VALUE BASED ON CONTINUOUS RECORDING FOR pH 4.5 AND THREE TIMES PER HOUR FOR 5.2, 5.9 AND 6.6; LOWER VALUE BASED ON GRAB SAMPLES) (SEE TEXT CONCERNING USE OF ARITHMETIC MEANS)

\begin{tabular}{|c|c|c|c|c|c|}
\hline \multirow[b]{2}{*}{ Item } & \multicolumn{5}{|c|}{ Nominal pH } \\
\hline & 4.5 & 5.2 & 5.9 & 6.6 & $\begin{array}{c}\text { Control } \\
7.5\end{array}$ \\
\hline \multirow[t]{2}{*}{ Number of measurements } & 358 & 356 & 354 & 356 & - \\
\hline & 87 & 85 & 86 & 84 & 234 \\
\hline \multirow[t]{2}{*}{ Mean } & 4.60 & 5.24 & 5.93 & 6.59 & - \\
\hline & 4.66 & 5.23 & 5.95 & 6.65 & 7.58 \\
\hline \multirow[t]{2}{*}{ Standard deviation } & 0.18 & 0.18 & 0.09 & 0.11 & - \\
\hline & 0.22 & 0.17 & 0.12 & 0.12 & 0.13 \\
\hline \multirow[t]{2}{*}{ Range } & $4.2-5.5$ & $4.4-7.4$ & $5.6-6.3$ & $6.1-7.0$ & - \\
\hline & $4.2-5.7$ & $4.7-5.5$ & $5.7-6.2$ & $6.3-6.9$ & $7.2-8.0$ \\
\hline
\end{tabular}

although not normally used, were employed in this instance because they appeared to portray conditions accurately enough for the intended purpose.) Extreme values were easily observed on the charts. The $\mathrm{pH}$ values of 4.5 and 5.2 were very difficult to control because the water's buffering capacity was exhausted, and any change in rate of loss of $\mathrm{CO}_{2}$ from the test chambers also altered the $\mathrm{pH}$.

\section{RESULTS}

Survival of fathead minnows was affected little, if at all, by 13 months continuous exposure to lowered $\mathrm{pH}$ (TABLE 3). However, at $\mathrm{pH} 4.5$, the lowest level tested, behavior of the young fish was abnormal for several months. When the $\mathrm{pH}$ approached 4.3 or 4.2, they showed stress (surface swimming and hyperactivity) even after 11 months acclimation to $\mathrm{pH} 4.5$. The fish appeared somewhat deformed, the heads in particular seeming smaller than normal.

The fish at $\mathrm{pH} 5.2$ were somewhat hyperactive, and the males especially had an abnormal "hunch-backed" appearance. Their heads were smaller than normal in proportion to their bodies. The females were heavy with eggs and were sexually mature based on gross examination, but did not spawn (TABLE 3).

At $\mathrm{pH} 5.9$ the fish appeared nearly normal, but a few showed mild symptoms of the deformities common at lower $\mathrm{pH}$ values. The males were not as brightly colored as those in the control and seemed to be more affected than the females. The number of eggs per female was reduced, and all eggs were abnormal. They had fragile shells, lacked turgidity, and were difficult to remove from the spawning tile for hatchability tests.

No abnormal effects were observed at $\mathrm{pH} 6.6$ except for a possible reduction in eggs produced, as compared to the control (TABLE 3). The onset of spawning was not affected at either $\mathrm{pH} 6.6$ or 5.9 , but hatchability was reduced at 5.9 , apparently because of the fragility of the eggs. This fragility has ecological importance, however, because such eggs when left with the male were smashed and destroyed by his normal cleaning actions.

Two groups of 50 eggs from each of three different control spawnings were placed 


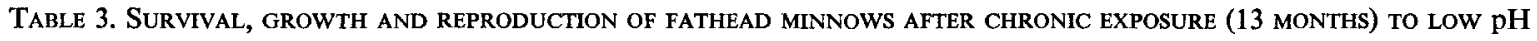

\begin{tabular}{|c|c|c|c|c|c|c|c|c|c|c|}
\hline \multirow[b]{3}{*}{ Item } & \multicolumn{10}{|c|}{ Nominal pH } \\
\hline & \multicolumn{2}{|c|}{4.5} & \multicolumn{2}{|c|}{5.2} & \multicolumn{2}{|c|}{5.9} & \multicolumn{2}{|c|}{6.6} & \multicolumn{2}{|c|}{$\begin{array}{c}\text { Control } \\
7.5\end{array}$} \\
\hline & A & $\mathbf{B}$ & A & $\mathbf{B}$ & A & B & A & B & A & B \\
\hline Survival $(\%)$ & 90 & 70 & 80 & 70 & 90 & 80 & 80 & 70 & 80 & 90 \\
\hline Number of males & 5 & 4 & 2 & 2 & 2 & 2 & 3 & 2 & 3 & 2 \\
\hline Number of mature females & 4 & 3 & 6 & 5 & 7 & 6 & 5 & 5 & 5 & $7 *$ \\
\hline \multicolumn{11}{|l|}{ Mean length at termination (mm) } \\
\hline Male & 70 & 70 & 79 & 80 & 77 & 78 & 68 & 64 & 69 & 72 \\
\hline Female & 59 & 60 & 60 & 61 & 60 & 60 & 55 & 58 & 55 & 53 \\
\hline Spawnings/female & 0 & 0 & $\mathbf{0}$ & 0 & 1.0 & 1.2 & 3 & 4 & 5.4 & 4.2 \\
\hline Hatchability (\%) & - & - & - & - & $55(4) \dagger$ & $29(3)$ & $78(7)$ & $82(10)$ & $79(11)$ & $78(15)$ \\
\hline Total number of eggs produced & $\mathbf{0}$ & 0 & $\mathbf{0}$ & 0 & 708 & 398 & 1061 & 1971 & 4837 & 2882 \\
\hline Number of eggs per female & - & - & 一 & - & 101 & 66 & 210 & 394 & 968 & 480 \\
\hline
\end{tabular}

* One was immature.

$\dagger$ Number of spawnings tested in parenthesis. 
in the control and in $\mathrm{pH} 4.5$ to test hatchability. For the three sets and average of 74 per cent hatched in the control (range (42-94 per cent) and 1 per cent (range 0-2 per cent) at $\mathrm{pH} 4.5$. Most mortality occurred in the first $48 \mathrm{~h}$ of incubation. The low $\mathrm{pH}$ greatly delayed the hatching time of the few eggs that did survive until hatching, and the embryos were grossly deformed. Similar comparisons at $\mathrm{pH} 5.2$ were made for 10 different egg masses; the control hatchability averaged 82 per cent (range $42-94$ per cent) and that at $\mathrm{pH} 5.2$ averaged 67 per cent (range 16-98 per cent). At pH 5.2 many deformities occurred, and the normal hatching period of 4-5 days was lengthened to 6-7 days.

Fry survival and growth were variable, thus reducing the value of this measurement of effect. The available data show no effect of $\mathrm{pH}$ on growth (TABLE 4); the lack of spawning at lower $\mathrm{pH}$ values prohibited growth measurements. The small number of spawnings, low hatchability, and egg fragility made it impossible to conduct duplicate tests of the growth of fry from eggs produced by fish at $\mathrm{pH} 5.9$.

The $\mathrm{TL}_{50}$ values in the acute tests were 4.05 and 4.2 . In one test all fish died in the chamber maintained between $\mathrm{pH} 3.6$ and 3.8, while all survived in $\mathrm{pH} 4.5-4.6$. In the other test 20 per cent survived $\mathrm{pH} 4.1-4.3$ and none died at 4.5. Since exact lethal levels were not essential and $\mathrm{pH}$ control was very difficult, no further refined testing was done.

TABLE 4. GROWTH AND SURVIVAL OF TWO GROUPS OF FATHEAD MINNOW FRY PRODUCED AND GROWN AT VARIOUS HYDROGEN-ION CONCENTRATIONS FOR 30 DAYS

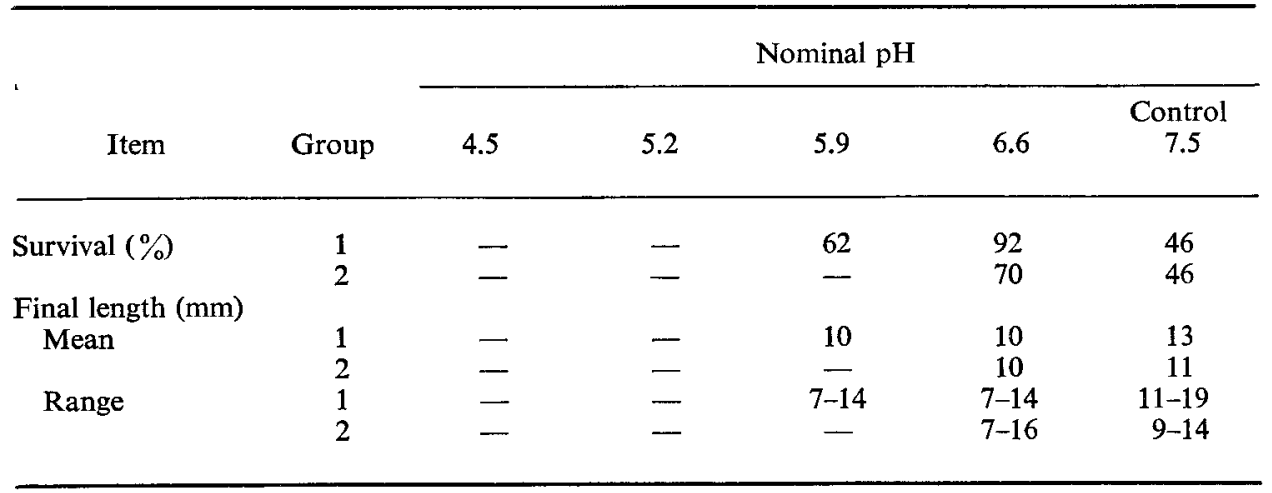

\section{DISCUSSION}

Clearly, a $\mathrm{pH}$ of 5.2 or less is unacceptable for this species and water type. The reduction in eggs per female and in hatchability at $\mathrm{pH} 5.9$ indicates that this level is marginal, a view further supported by incompleted tests not included here. The lack of true duplicates in the exposure prohibits valid statistical comparisons.

The results of these tests support earlier published work (EUROPEAN INLAND Fisheries ADVISORY COMmission, 1969) in refuting the commonly held belief that fishes become acclimated to low $\mathrm{pH}$ levels. Fish in this test did not acclimate even after 12 months exposure. When the $\mathrm{pH}$ approached 4.2 in the tank at nominal $\mathrm{pH}$ 4.5 as it occasionally did, the fish showed marked distress comparable to that displayed by control fish exposed to the same $\mathrm{pH}$. The marked effect on spawning at nonlethal $\mathrm{pH}$ levels is important ecologically and could easily be overlooked in field studies 
because of recruitment from adjacent stream areas. The lack of growth effects noted by others in natural waters is consistent with the absence of growth effects found in this study. Furthermore, the lower productivity attributed in the literature to reduced food could be equally attributed to reduced egg production. The tolerance of several aquatic insects to low pH (BELL and NEBEKER, 1969; BeLL, 1970) suggests that decreased productivity is not likely to be related to reduced insect populations.

Water quality standards allowing $\mathrm{pH}$ values lower than 6 will not provide protection for this species. Observations of ElLIS (1937) that 97 per cent of the locations having good fish populations had $\mathrm{pH}$ values between 6.7 and 8.6 are consistent with these laboratory data. The evidence collectively supports the need to maintain $\mathrm{pH}$ at or above 6.5. Even though sustained fish populations may exist at lower $\mathrm{pH}$ levels, production will most likely be reduced.

The reproductive impairment noted at $\mathrm{pH}$ levels at least two units higher than lethal $\mathrm{pH}$ levels, and yet the absence of growth effects, illustrates the need for additional chronic (full life cycle) tests with other important species to develop data for establishing water quality standards.

Acknowledgements-I thank Mr. JAMES DRYER for data processing, Mr. KERMIT FIGART for daily water analyses and Messrs. Q. Pickering, J. G. EATON and Dr. W. Brungs for help on weekends and holidays during the 13 months of the test.

\section{REFERENCES}

BeLl H. L. (1970) Effects of pH on the life cycle of the midge, Tanytarsus dissimilis. Can. Entomol. 102, 636-639.

Bell H. L. and Nebeker A. V. (1969) Preliminary studies on the tolerance of aquatic insects to low pH. J. Kans. Entomol. Soc. 42, 23-236.

Ellis M. M. (1937) Detection and measurement of stream pollution. U.S. Dept. Comm. Bur. Fish. Bull. 22, 364-437.

EUROPEAN INLAND Fisheries Advisory COMMISSION (1969) Water quality criteria for European freshwater fish-extreme $\mathrm{pH}$ values and inland fisheries. Water Research 3, 593-611.

LloYD R. and JoRDAN D. H. M. (1964) Some factors affecting the resistance of rainbow trout (Salmo gairdnerii Richardson) to acid waters. Int. J. Air Water Pollut. 8, 393-403.

MounT, D. I. (1968) Chronic toxicity of copper to fathead minnow (Pimephales promelas Rafinesque). Water Research 2, 215-223.

Mount, D. I. and Brungs W. A. (1967) A simplified dosing apparatus for fish toxicology studies. Water Research 1, 21-29.

Mount, D. I. and StePHAN C. E. (1969) Chronic toxicity of copper to the fathead minnow (Pimephales promelas) in soft water. J. Fish. Res. Board Can. 26, 2449-2457.

MOUNT D. I. and WARNER R. E. (1965) A serial-dilution apparatus for continuous delivery of various concentrations of materials in water. U.S. Dep. Health, Educ., Welfare, Public Health Serv. Publ. 999-WP-23. 16 p. 